\title{
Consumers' perceptions of risks associated with the use of Airbnb before and during the COVID-19 pandemic
}

\author{
Seung Hyun Lee and Cynthia Deale \\ East Carolina University, Greenville, North Carolina, USA
}

Consumers' perceived risks of using

Airbnb

Received 20 September 2020

Revised 25 November 2020 5 February 2021

Accepted 5 March 2021

\begin{abstract}
Purpose - After the COVID-19 outbreak began, travel demand dropped sharply and the potential impact of COVID-19 on sharing accommodations appears to be significant. Thus, it would be meaningful to investigate how travelers have changed their perceptions of staying at sharing accommodations in the wake of the coronavirus pandemic. The purpose of this research was to compare consumers' perceived risks of using sharing accommodations, such as Airbnb, before and during the coronavirus pandemic.

Design/methodology/approach - Paired sample $t$-tests were applied, using two surveys collected in 2017 (pre-pandemic) and 2020 (peri-pandemic). The effects of stress levels from COVID-19 and previous experience with sharing lodging services on risk perception changes were also examined.

Findings - Consumers showed higher social, physical, performance and convenience risk perceptions during the pandemic. Not surprisingly, those respondents who were more conscious of the pandemic in terms of concern and anxiety had higher changes in their risk perceptions. In addition, changes in risk perception differed by consumers' usage experience.

Originality/value - The results of this study add to the body of knowledge about consumers' risk perceptions of the sharing economy, particularly in connection with a huge disruption such as the COVID-19 pandemic.
\end{abstract}

Keywords Sharing economy, Perceived risk, Consumer perception change, Short term rentals, Risk aversion, Usage experience

Paper type Research paper

\section{Introduction}

In the sharing economy, individuals and groups obtain, borrow and share access to physical assets through a peer-to-peer platform where information is shared and products and services are bought and sold (Hamari et al., 2016). Airbnb, a major participant in the sharing economy, allows property owners rent out their properties or rooms to guests (Airbnb, 2020; Guttentag, 2015). Founded in 2008, Airbnb generates its revenue through service fees to hosts and guests; it costs guests a $6-12 \%$ fee and hosts a 3\% fee (Guttentag, 2015). In 2018, Airbnb was valued at 38 billion US dollars (Statista, 2019), and in 2020, it offered over 7 million accommodations provided by local hosts and operated in 220 countries and regions (Airbnb, 2020).

However, the COVID-19 pandemic has had negative impacts on the hospitality and tourism industries. With home sharing comprising an estimated $10 \%$ of US consumer spending on overnight stays, the impacts of this economic crisis will surely be felt by people who share their assets on Airbnb (Taylor, 2020). According to data about Airbnb hosts, more

(C) Seung Hyun Lee and Cynthia Deale. Published in International Hospitality Review. Published by Emerald Publishing Limited. This article is published under the Creative Commons Attribution (CC BY 4.0) licence. Anyone may reproduce, distribute, translate and create derivative works of this article (for both commercial and non-commercial purposes), subject to full attribution to the original publication and authors. The full terms of this licence may be seen at http://creativecommons.org/licences/by/4.0/ legalcode

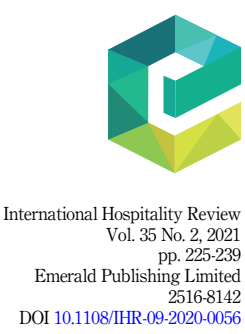


IHR

35,2

than half of them use Airbnb income to help them afford their homes, nearly half use Airbnb income to supplement expenses, and nearly one in five indicate that Airbnb helps them avoid eviction or foreclosures (Ovide, 2020).

After the COVID-19 outbreak began, travel decreased sharply and the potential impact of COVID-19 on sharing accommodations appears to be significant (Airbnb, 2020; UNWTO, 2020). Due to the pandemic, sanitation, cleanliness and hygiene have become more important to people (Yuko, 2020). Thus, it would be meaningful to investigate how travelers have changed their perceptions of staying at an Airbnb, in the wake of the pandemic. Therefore, the objective of this study was to compare consumers' perceived risks associated with using Airbnb, before (pre-pandemic) and during the coronavirus pandemic (peri-pandemic). This was a replication study where the method adopted in the second study was as close to the original as possible. The main reason for replication was to test if changing social, economic and political conditions due to the pandemic might impose different outcomes. The following research question guided this study:

$R Q 1$. How have consumers' perceptions changed toward the risks associated with using Airbnb before and during the coronavirus pandemic?

\section{Literature review}

\section{Sharing economy}

As noted, the sharing economy is centered on individuals directly sharing assets or services, for free or for a fee (Botsman, 2015). The sharing economy involves a variety of businesses, including several in the travel industry, such as Outdoorsy (2020) that allows consumers to rent a recreational vehicle (RV) and Airbnb (2020) that permits a host to rent a lodging accommodation to a guest.

As a disruptor in the economy, sharing economy lodging options tend to be cheaper, more convenient and easier to use than traditional lodging accommodations (Christensen, 2013; Zervas et al., 2017) and may be viewed as being like home (Cheng and Jin, 2019: Zhau et al., 2019). Plus, the sharing economy accommodations may create a new market (Guttenberg, 2015); one research study has found that $30 \%$ of Airbnb users would not have visited the destination or stayed as long if the option had not been available (Guttentag and Smith, 2017).

Some traditional lodging providers have chosen to ignore sharing accommodations, as they do not think that the sharing economy is in direct competition with them (Heo et al., 2019), but others are worried (Guttentag, 2015). For instance, given that sharing accommodations are often used by low budget, leisure travelers, traditional accommodations that are directed toward that particular market may be negatively impacted by the growth of sharing accommodations (Guttentag and Smith, 2017; Young et al., 2017; Zervas et al., 2017).

\section{Airbnb as a major participant in the sharing economy}

As a sharing accommodation, Airbnb has been characterized by its lower costs (Zervas et al., 2017) and high level of host involvement (Nguyen, 2014). In several studies, Airbnb consumers reported that the sharing economy lodging option provided them with benefits regarding pricing and amenities, and they had intrinsic motivations for its use, such as trust (e.g. Hamari et al., 2016; Ert et al., 2016; Mao and Lyu, 2017; So et al., 2018). While opinions of Airbnb may be largely positive (Bridges and Vasquez, 2018), consumers have also conveyed complaints, constraints and/or risks associated with staying in these accommodations (e.g. Liang, 2015; Phua, 2019). For example, customers have noted service and technology challenges and expressed reduced trust (Phua, 2019) and potential risks related to a lack of regulation (Mao and Lyu, 2017). 
Perceived risk (Jun, 2020; Liang et al., 2018; Lee, 2020) and lack of trust (Tussyadiah and Pesonen, 2016; Xie and Mao, 2017; Zhenxing et al., 2020) have been explored as obstacles to the use of Airbnb. Results of previous studies have indicated that distrust predicts overall attitude toward Airbnb, and insecurity with the product is directly related to behavioral intention to use a shared lodging accommodation (So et al., 2018). In addition, Airbnb users develop risk perceptions based on their previous experiences with Airbnb (Liang, 2015).

A recent study by Lee (2020) provided initial insights into the reasons why consumers avoid sharing accommodations and identified potential benefits and risks in relation to attitude and behavioral intentions prior to the pandemic. The results indicated that both perceived risks and benefits influence consumers' attitudes toward sharing economy accommodations, which result in higher intentions to buy sharing accommodations and services. That finding was somewhat consistent with previous research (So et al., 2018) that found that motivations (i.e. price, enjoyment and home benefit) and constraints (i.e. distrust and social influence) impact overall attitude, bringing about behavioral intentions toward Airbnb.

\section{COVID-19 and hospitality and tourism}

As the COVID-19 pandemic continues, many businesses have seen a loss in revenue or closed, and travel and tourism may be impacted for many years (Gradek, 2020). According to the United Nations (U.N.) (2020a), international tourist numbers could decrease between 58 and $78 \%$ in 2020 alone, signifying a huge decline in visitor spending between 2019 and 2020, placing over 100 million tourism jobs in jeopardy around the globe (UNWTO, 2020b).

However, recently tourism has seen a slow, cautious change in the positive direction, with some travel restrictions starting to be lifted in a few countries, some international flights returning and some domestic and interregional travel markets reopening (UNWTO, 2020a). Domestic tourism is expected to rebound sooner than international travel, with changes such as more trips being taken closer to home, bookings being made closer to the departure dates of the trip, a preference for car travel (UNWTO, 2020a) and an increase in the purchase, rental and use of RVs (Sozzi, 2020). However, although travel may begin to increase, consumers' concerns about the risks associated with travel continue (UNWTO, 2020a). It appears that the recovery will continue to be slow and intermittent, and experts warn that changes in industry practices will be needed for success in the future (Ipsos, 2020).

\section{COVID-19 and the sharing economy, focusing on Airbnb}

As far as sharing economy accommodations are concerned, Airbnb CEO Brian Chesky noted in May of 2020 that revenues could decline more than $50 \%$ during the year, prompting him to cut costs, raise $\$ 2$ billion in capital and let 1,900 employees go (25\% of the total) (Airbnb, 2020a, online). As the summer of 2020 progressed, revenues did decline, but Airbnb experienced more booked nights for US listings between May 17 and June 3 of 2020 than during the same period in 2019 and saw a similar increase in domestic travel globally (Roof and Carville, 2020). Recent projections are that Airbnb could thrive, as customers see the accommodations as being much less risky than traditional hotels with regard to the spread of the virus (Mohamed, 2020). Yet, while previous studies helped to clarify consumers' perceived risks of using shared economy accommodations prior to the pandemic, little is known about their perceptions of risks during the pandemic, nor have comparisons been made in terms of any changes in their views.

\section{Perceived risk}

Risk is defined as the probability and adverse consequences of an uncertain outcome before and during purchase (Bart et al., 2005; Stone and Gronhaug, 1993; Grewal et al., 2007; 
Kushwaha and Shankar, 2013). In comparison to tangible products, the role of perceived risk is more salient for services due to greater intangibility derived from lack of physical evidence of the product offered (Boshoff, 2002; Cunningham et al., 2005; Laroche et al., 2004; Murray and Schlacter, 1990; Sun, 2014). In addition, the consumer's personal involvement with service causes social and psychological losses to be more salient for services than for goods (Laroche et al., 2004; Murray and Schlacter, 1990; Sun, 2014).

Consequently, for services, perceived risk is a major factor influencing consumer choice (Gefen and Pavlou, 2012; Grewal et al., 1994; Stone and Gronhaug, 1993; Xie and Mao, 2017), and risk exerts a strong effect on behavioral intentions. Perceived quality of the service provider diminishes perceived risk and thereby, perceived risk reduces behavioral intentions, while perceived quality of the service provider enhances behavioral intentions (Grewal et al., 2007). That explains why provision of the brand guarantee improves expected quality and reduces perceived risk (Lee and Khan, 2012; Wirtz et al., 2000). Brand credibility leads to increased perceived quality and decreased perceived risk, which results in the effects on purchase intention across multiple service categories (Baek and Karen, 2011; D’Alessandro et al., 2012).

In one study, researchers found that risk perceptions can be reduced by providing general service information, price information and a service guarantee in a printed advertisement (Boshoff, 2002). In another study, Pires et al. (2004) found that there was no association between the frequency of online purchasing and perceived risk, although satisfaction with prior Internet purchases was negatively associated with the perceived risk of intended purchases. Yang et al. (2015) proposed the uncertainty-risk-value framework and found that perceived information asymmetry, perceived technology uncertainty, perceived regulatory uncertainty and perceived service intangibility are identified as the main determinants of perceived risk, while perceived performance risk, perceived financial risk and perceived privacy risk were found to have strong negative effects on perceived value and acceptance intention.

\section{Development of hypotheses}

Due to the lack of knowledge about consumers' perceived risk with regard to staying in Airbnb accommodations during the pandemic, this study compared consumers' risk perceptions before the pandemic to their perceptions during the pandemic, based on the following dimensions of perceived risk: social, psychological, psychological, financial, convenience and performance (Bart et al., 2005; Kushwaha and Shankar, 2013; Laroche et al., 2004; Anderson et al., 2016; Stone and Gronhaug, 1993). This study examined the following four dimensions of perceived risk that are relevant in the context of sharing services (Lee, 2020):

\section{(1) Social risk}

- a loss such that the choice may result in embarrassment and loss of self-esteem before family or friends (Kushwaha and Shankar, 2013; Murray and Schlacter, 1990; Skard and Nysveen, 2016).

(2) Physical risk

- related to safety and potential hazards or harms associated with the purchase or use of goods (Murray and Schlacter, 1990).

(3) Performance risk

- the loss incurred when the service does not perform as expected (Kushwaha and Shankar, 2013; Sweeney et al., 1999). 
(4) Convenience risk

Consumers'

- addresses the loss of time and effort associated with the purchase and highlighted the possibility that the service will fail to deliver the desired benefits (Skard and Nysveen, 2016).

Effects of risk have been shown to be contingent on contextual and individual factors (Curran and Meuter, 2005; Skard and Nysveen, 2016), including consumer decision-making processes that may vary under differing environmental conditions, with the level of uncertainty viewed on a continuum ranging from very stable to very unstable (Dean and Sharfman, 1993). In a stable environment, conditions are well understood and can easily be factored into decisions and thus, enable consumers to anticipate with some certainty and plan for change based on experience and past information. However, the rate of change in the environment can be extreme when a change is rapid and discontinuous (Bourgeois and Eisenhardt, 1988), such as that caused by a pandemic. Effective decision-making can be challenging in this rapid, unstable environment not only because a change is so dramatic, but also because it is difficult to predict the significance of a change as it is occurring (Sutton et al., 1986).

When consumers replace traditional lodging services with a sharing service, especially during the pandemic, they may be concerned that the performance of the shared lodging accommodation may not be as consistent as that of hotels (Lee, 2020). Uncertainty due to the pandemic may exert a stronger perceived risk in using sharing services and push consumers away from the idea of renting from strangers because sharing providers are more likely to be unregulated and unsupervised (Young et al.,2017; Mody et al.,2017). Thus, it is proposed that consumers perceive higher risk during an unpredictable and uncertain environment, leading to $\mathrm{H} 1$ :

H1. There are significant changes between consumers' risk perceptions regarding staying at sharing accommodations pre-pandemic and peri-pandemic.

Still, although consumers may perceive higher risk overall during the pandemic, individuals differ with respect to the risk they can tolerate, often called risk aversion, resulting in different attitudes toward risk (Baz et al., 1999; Sun, 2014). Not surprisingly, risk aversion influences the ways consumers make purchasing decisions (Baz et al., 1999; Shimp and Bearden, 1982), and consumers' risk assessment is influenced by how sensitive they are to risk (Havlena and DeSarbo, 1991). For example, consumers with low risk aversion feel less threatened by ambiguous conditions, while those with high risk aversion feel more threatened (Sun, 2014). Similarly, it can be concluded that consumers show different levels and types of sensitivity and anxiety toward the risk of the coronavirus, which influence their risk perceptions regarding staying at sharing accommodations, leading to $\mathrm{H} 2$ :

H2. Higher changes in risk perceptions of staying at sharing accommodations, prepandemic and peri-pandemic, are seen among consumers who are more concerned about the coronavirus.

Consumers' risk perceptions may also be impacted by their previous experiences, for previous studies have revealed that usage experience influences consumer attitude and actual consumption (Thompson et al., 1994). Experience is a general term that involves knowledge or skills about an object/event gained through the involvement in or exposure to that object/event (Shen et al., 2011), and more specifically usage experience is often measured by asking individuals to self-report their experience with the product category, such as whether they have used, owned, or searched for information about the product (Raju et al., 1995). Interestingly, scholars have found that subjective norms became less important with increasing experience (Karahanna et al., 1999). Therefore, consumers will use their prior 
IHR

35,2

experience as a reference point to infer product quality and refine their choices. Consequently, changes in risk perceptions may differ by usage experience (whether they have used a sharing lodging service), leading to $\mathrm{H} 3$ :

H3. Changes in risk perceptions of staying at sharing accommodations, pre-pandemic and peri-pandemic, differ by consumers' usage experience.

\section{0}

\section{Methodology}

To examine how consumers have changed their risk perceptions of Airbnb since the COVID19 pandemic began, this replication study was conducted for comparison. The results of the first survey conducted in February of 2017 (pre-pandemic) were adopted from a research study completed previously by Lee (2020). For the replication survey, the same method was adopted to be as close to the original as possible, to allow for comparison. The data for the second survey were collected in March of 2020 (peri-pandemic).

The scale used in this study was adapted from Lee's (2020) study. It included four items of social risk (Cronbach's $\alpha_{\text {pre }}=0.928 ; \alpha_{\text {peri }}=0.907$ ), four items of physical risk (Cronbach's $\alpha_{\text {pre }}=0.847 ; \alpha_{\text {peri }}=0.782$ ), three items of performance risk (Cronbach's $\alpha_{\text {pre }}=0.689$; $\left.\alpha_{\text {peri }}=0.712\right)$ and three items of convenience risk (Cronbach's $\alpha_{\text {pre }}=0.778 ; \alpha_{\text {peri }}=0.717$ ). A 5-point Likert scale was used ( $1=$ "strongly disagree" and $5=$ "strongly agree") (see the Appendix).

In addition, six questions related to COVID-19 were asked to measure concern levels due to the pandemic (e.g. I am concerned about getting COVID-19). A 5-point Likert scale, ranging from 1 being "strongly disagree" to 5 being "strongly agree," was used. Questions related to travel patterns such as frequency of travel per year, the main purpose of their most recent trip and previous experience with sharing accommodations were also asked. Finally, questions related to demographic information (e.g. age, gender and income) were asked.

Convenience sampling was used because it allowed the researchers to obtain data in a relatively easy manner. A consumer panel sample was recruited through a marketing research firm called MTurk, which was the same the platform used in 2017 (Lee, 2020). When validating online tools, Buhrmester et al. (2016) analyzed the demographic characteristics of samples obtained via MTurk and found that the quality of data met or exceeded the psychometric standards associated with the published research.

Data analysis applied SPSS 26 and paired sample $t$-tests were used to compare changes in risk perceptions between the consumers' pre-pandemic and peri-pandemic. $t$-tests were used to investigate the effects of stress levels from COVID-19 and previous experience with sharing economy lodging services on risk perception changes.

\section{Results \\ Sample}

For the pre-pandemic survey data analysis (data collected in 2017), 309 surveys were used. The sample consisted of $66 \%$ females and $34 \%$ males, $76 \%$ were 34 years old or younger, $7 \%$ stated that they traveled 3-5 times annually, and most respondents $(81 \%)$ indicated that they had previously used sharing accommodations (Lee, 2020).

In the peri-pandemic survey, 304 responses were used for data analysis. The sample consisted of more male $(74 \%)$ than female $(26 \%)$ respondents; $72 \%$ of them were younger than 34 years old, and their annual household income varied. Sixty percent reported that they travel 3-5 times a year and $80 \%$ had used a sharing lodging service (e.g. Airbnb). In addition, the respondents were asked how long they thought it would take for them to resume their normal travel. Forty-seven percent of them said 3 months and $31 \%$ said 6 months, followed by 9 months $(10 \%)$, less than 1 month $(6 \%)$ and more than 12 months $(6 \%)$. When they 
resumed their normal travel, they indicated that their main purposes for traveling would be business $(51 \%)$, visiting friends and family $(30 \%)$ and leisure $(19 \%)$. Their choice of an accommodation would be the following: a midscale hotel (32\%), an economy hotel (29\%), an upscale hotel $(20 \%)$ and a luxury hotel $(9 \%)$; whereas $10 \%$ of them would choose short term rentals such as Airbnb.

\section{Hypothesis testing}

H1. Risk perception changes were examined by comparing the pre-pandemic and peripandemic perceptions. The overall average pre-COVID-19 social risk was 2.64; physical risk was 3.27; performance risk was 3.54, and convenience risk was 3.19. Results of the peripandemic indicated that the overall average peri-COVID-19 social risk was 3.28; physical risk was 3.63; performance risk was 3.79, and convenience risk was 3.64. As seen in Table 1, paired sample $t$-tests confirmed that perceived risk changes were significant: social risk $(\Delta=0.64$, $t=6.856, p<0.001)$, physical risk $(\Delta=0.35, t=4.978, p<0.001)$, performance risk $(\Delta=0.24$, $t=3.523, p<0.001)$ and convenience risk $(\Delta=0.45, t=6.186, p<0.001)$, supporting H1. Interestingly, social risk change $(\Delta=0.64)$ was larger than other risk changes.

H2. Risk perception changes were examined by consumer anxiety levels, such as their state of mind regarding the pandemic. They were concerned about getting COVID-19 $(m=3.85)$, the outbreak made them remain in a state of nervous tension $(m=3.80)$, they felt vulnerable ( $m=3.76)$, and the outbreak made them feel sad and depressed ( $m=3.67$ ). The respondents also thought that the outbreak makes them feel scared easily $(m=3.66)$ and their chances of getting infected are high $(m=3.51)$.

The respondents included in the peri-pandemic data were classified into the following two groups by their levels of concern: more concerned (152 respondents) and less concerned (151 respondents). As expected, the more concerned group had higher anxiety levels due to COVID-19 than the less concerned group $\left(M_{\text {more concerned }}=4.31\right.$ vs. $M_{\text {less concerned }}=3.10$, $t=427.254, p<0.001$ ). As shown in Table 2 , the more concerned respondents exhibited higher perceived risk changes than the less concerned group: social risk $\left(\Delta_{\text {more concerned }}=0.98\right.$ vs. $\left.\Delta_{\text {less concerned }}=0.27, t=15.604, p<0.001\right)$, physical risk $\left(\Delta_{\text {more concerned }}=0.67\right.$ vs. $\left.\Delta_{\text {less concerned }}=0.03, t=22.327, p<0.001\right)$, performance risk $\left(\Delta_{\text {more concerned }}=0.52 \mathrm{vs}\right.$.

\begin{tabular}{lllcc}
\hline & Social risk & Physical risk & Performance risk & Convenience risk \\
\hline Pre-COVID -19 & $2.64(1.15)$ & $3.27(0.87)$ & $3.54(0.89)$ & $3.19(0.93)$ \\
Peri-COVID -19 & $3.28(1.13)$ & $3.63(0.83)$ & $3.79(0.80)$ & $3.64(0.82)$ \\
$t$ & 6.856 & 4.978 & 3.523 & 6.186 \\
$p$ & 0.000 & 0.000 & 0.000 & 0.000
\end{tabular}

Note(s): Standard deviations are in parenthesis

Note(s): Standard deviations are in parenthesis

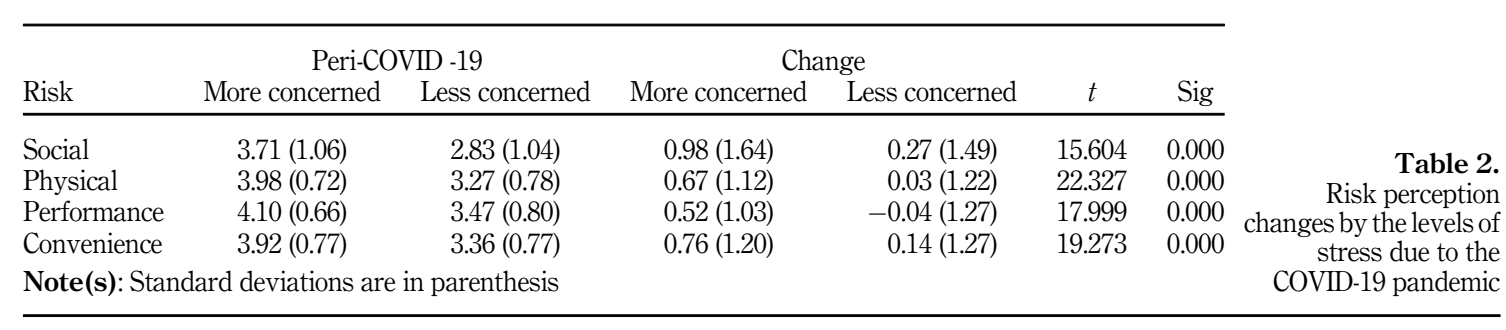

Consumers' perceived risks of using Airbnb

Table 1. Risk perception changes (peripre-test) 
IHR

35,2

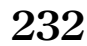

$\left.\Delta_{\text {less concerned }}=0.04, t=17.999, p<0.001\right)$ and convenience risk $\left(\Delta_{\text {more concerned }}=0.76 \mathrm{vs}\right.$. $\Delta_{\text {less concerned }}=0.14, t=19.273, p<0.001$ ), supporting $\mathrm{H} 2$.

H3. Lastly, risk perception changes were investigated by consumer usage experience. Based on the peri-pandemic data, the respondents were classified into the following two groups by their usage experience (whether they have used a sharing lodging service): yes (243 respondents) and no (60 respondents). Table 3 reveals that those respondents who had used a sharing lodging service displayed a higher perceived social risk change than the those without experience: $\operatorname{social}$ risk $\left(\Delta_{\text {yes }}=0.73\right.$ vs. $\left.\Delta_{\text {no }}=0.26, t=4.150, p<0.05\right)$. Conversely, the respondents who had not used a sharing service showed a higher perceived performance risk change than those with experience: performance risk $\left(\Delta_{\text {yes }}=0.14\right.$ vs. $\Delta_{\text {no }}=0.64, t=8.572$, $p<0.05$ ), thus partially supporting H3.

\section{Discussion}

As noted, there were significant changes between consumers' risk perceptions regarding staying at sharing accommodations pre-pandemic and peri-pandemic, supporting hypothesis 1. Consumers showed higher social, physical, performance and convenience risk perceptions peri-pandemic. Interestingly, the social risk changes were greater than other risk factors. This view may be connected to brand image issues associated with sharing economy accommodations, especially during the pandemic. Consumers increased their perception of the risk of having a host become hostile, and perhaps this is not surprising given the difficult situation that the pandemic has created for both hosts and guests. Hosts may be concerned about losing revenue and having to engage in enhanced cleaning procedures (e.g. e.g. Airbnb, 2020b), while guests may be worried about having a host become upset if they complain about the cleanliness of the accommodations or use the cancellation policy. This finding might also connect to the respondents' perceptions that if something goes wrong during check-out, there may be no one on site to help, suggesting that a lack of service may be an issue.

Not surprisingly, consumers showed different levels and types of sensitivity and anxiety toward the risk of the coronavirus, which influenced their risk perceptions regarding staying at sharing accommodations. Higher changes in risk perceptions of staying at sharing accommodations, pre-pandemic and peri-pandemic, were observed among respondents who were more concerned about the coronavirus, supporting hypothesis 2 . This result was expected, but it highlights the impact of people's concerns about the pandemic, and the finding that those with higher levels of risk aversion had increased risk perceptions related to staying in sharing accommodations is similar to previous findings regarding consumer purchasing decisions (e.g. Sun, 2014; Havlena and DeSarbo, 1991).

In addition, some changes in risk perceptions regarding staying in sharing accommodations, pre-pandemic and peri-pandemic, differed by consumers' usage experience, partially supporting H3. This finding concurs with previous research that found that usage impacts consumer attitudes and consumption (Thompson et al., 1994).

Table 3.

Risk perception changes by usage experience

\begin{tabular}{lcccccc}
\hline & \multicolumn{2}{c}{ peri-COVID -19 } & \multicolumn{2}{c}{ Change } & & \\
& Yes & No & Yes & No & $t$ & Sig \\
\hline Social & $3.31(1.16)$ & $3.14(1.01)$ & $0.73(1.65)$ & $0.26(1.33)$ & 4.150 & 0.043 \\
Physical & $3.67(0.82)$ & $3.46(0.86)$ & $0.34(1.21)$ & $0.38(1.24)$ & 0.040 & 0.841 \\
Performance & $3.80(0.81)$ & $3.73(0.75)$ & $0.14(1.15)$ & $0.64(1.26)$ & 8.572 & 0.004 \\
Convenience & $3.68(0.94)$ & $3.50(0.90)$ & $0.44(1.30)$ & $0.50(1.17)$ & 0.107 & 0.743 \\
Note(s): Standard deviations are in parenthesis & & & & \\
\hline
\end{tabular}


Overall, changes in social risks were higher than other risk factors and this was especially the case with those who had stayed at a sharing accommodation. Once again, perhaps this is connected with a lack of a cohesive, positive brand image. Additionally, the result may be connected to how much consumers attend to the views that they think others have of them, and that issue is perhaps worth further study to understand more about social risk perceptions. Those who had not used sharing economy accommodations held higher changes in performance risk perceptions, thinking that the images of the properties were not accurate and that hotels are more reliable choices.

While several items had significantly different means between the pre-pandemic and peri-pandemic surveys, interestingly several items that might be seen as related to the pandemic did not show differences. For instance, the perceptions of cleanliness were not much different and possibly one might think that those would change considerably between the pre-pandemic and peri-pandemic survey (See Appendix). However, Airbnb (2020b) launched an enhanced cleaning protocol in the spring of 2020 and the respondents may have been aware of these higher standards. Conceivably they may understand, as noted by infectious disease experts, that renting a property offered by Airbnb, is typically seen as safer than renting a hotel room because there is less direct person-to-person contact and reducing person-to-person contact is seen as critical to reducing the spread of the coronavirus (Dubin, 2020).

\section{Implications}

As noted, by the findings related to $\mathrm{H} 1$, respondents already believed that there were some social, physical, performance and convenience risks associated with staying in sharing economy accommodations prior to the pandemic and those perceived risks seemed to be heightened by the pandemic. Interestingly, one study, comparing hotels to sharing economy accommodations, found that hotels performed just as well as Airbnb with regard to being hospitable (Mody et al., 2019), a social risk factor. However, hosts are not often present at a shared economy accommodation, and communication between a guest and host is typically conducted online and limited, sometimes with a manager attending to the accommodation that may not own the property, live in it, or be very familiar with it. Perhaps more information could be shared between hosts and guests and more interaction, with a more intentional focus on being hospitable, could be encouraged through Airbnb, for the safety and well-being of both guests and hosts.

With regard to risk perceptions, accurate photos played a role, and they may be particularly meaningful during the pandemic. Given that consumers changed their perceptions such that they were less likely to believe that the photos honestly portray the accommodations, it would be wise for hosts to update their photos and ensure that the images truly reflect the accommodations accurately to provide guests with realistic views of their properties.

As observed in the results of the study, higher changes in risk perceptions of staying at sharing accommodations, pre-pandemic and peri-pandemic, were found among the respondents who were more concerned about the coronavirus. Again, communication may help to mitigate these risk perceptions and therefore, it would be wise for managers of online sharing economy platforms and hosts of sharing accommodations to clearly articulate the measures being applied to ensure the safety, well-being and peace of mind of their guests. Furthermore, once again, perhaps a more intentional focus on service is needed, including host-guest interactions that are authentic, genuine, friendly and helpful.

As noted above, several changes in risk perceptions regarding staying in sharing accommodations, pre-pandemic and peri-pandemic, varied by consumers' usage experience. This finding may also indicate that more meaningful communication and better service, in
Consumers' perceived risks of using

Airbnb 
IHR

35,2

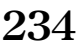

terms of attention to the guest and to the property itself, could be warranted to help diminish these negative perceptions.

\section{Implications for the sharing economy: Airbnb}

The findings of the study indicate that due to the pandemic, sharing economy accommodation providers should be sure to carefully develop, implement and articulate their cancellation policies, cleaning policies and what they will do if a previous guest is found to have COVID-19. In addition, providers would do well to carefully determine and communicate what their buffer policy is, in terms of how many hours occur between when guests check-out and the next guests check into an accommodation.

Generally, to mitigate risks of all kinds, those involved in the leadership, management and maintenance of lodging properties, including sharing economy brands, need to be flexible and adapt to change (Ipsos, 2020). Traditional hotels have often been seen as better providers of service than those offered via the sharing economy due to high levels of person-to-person contact, but the pandemic may have changed that view due to the ways that sharing accommodations operate. Providers of sharing economy accommodations typically already have some safety measures in place such as limited to no-contact check-in procedures, no lines of guests waiting to check in, and many do not have elevators, which may be activities or spaces where the virus could potentially spread.

Furthermore, hosts would do well to consider how service can be offered and seen positively by guests even though the hosts may not be physically present at the property. The findings may help sharing service providers better understand heightened perceived risk and help support the development of appropriate strategies to mitigate the risk concerns consumers have regarding using a sharing lodging service, especially during the pandemic. Carrying out thoughtful, competent, caring, intentional, authentic service activities can possibly help to mitigate consumers' perceived risks and include, but are not limited to the following:

(1) Maintaining ongoing communication between guest and host;

(2) Clearly articulating the cleanliness, amenities and safety of the accommodations;

(3) Following up promptly if any issues arise; and

(4) Making guests feel welcome from their first encounter to their last, which could be from when a guest seeks out a property online until the guest provides a review after his/her/their stay.

\section{Conclusions, limitations and suggestions for future research}

While the results of this study add to the body of knowledge about consumers' perceptions of the sharing economy, particularly in connection with the COVID-19 pandemic, the study has several limitations. These include that the sample was relatively small and restricted to a consumer panel; a larger, more diverse sample might have yielded different results. In addition, the respondent groups differed in composition between the pre-pandemic and peripandemic survey. Ideally researchers would want to use the same respondent group for paired comparison, but due to limited resources and time, two different panels were used. Although the researchers kept the source of the panel and sample size consistent, differences between views based on individual characteristics such as gender could potentially influence the results. Future research could investigate risk perceptions of shared economy lodging further through investigations based on demographic aspects. Further studies might also consider comparisons between changes in perceptions of shared economy lodging and 
traditional lodging options pre-pandemic and peri-pandemic. It is possible that not just perceptions of using sharing accommodations have been negatively affected by the pandemic. For example, it is conceivable that those with high anxiety, stress and concern over the coronavirus might not only have increased risk perceptions about staying in sharing accommodations, but also about staying in traditional hotels, dining inside restaurants and attending events.

In conclusion, the respondents perceived increased risks regarding staying in Airbnb accommodations during the pandemic. It is recommended that sharing service providers ensure that they are flexible; adapt to ongoing changes; provide consistent, thoughtful service; offer carefully crafted online information, including accurate images; communicate effectively with potential guests and current guests; and consider potentially revisiting, revising and even reinventing the way that they provide service. By doing so, customers will remain loyal to sharing services following the end of the pandemic.

\section{References}

Airbnb (2020), “About us”, available at: https://news.airbnb.com/about-us/ (accessed 24 August 2020).

Airbnb (2020a), "A message from co-founder and CEO Brian Chesky", available at: https://news. airbnb.com/a-message-from-co-founder-and-ceo-brian-chesky/ (accessed 26 August 2020).

Airbnb (2020b), “Airbnb enhanced clean”, available at: https://www.airbnb.com/d/enhancedclean (accessed 28 August 2020).

Anderson, S., Silva, A. and de, L.B. (2016), "Understanding consumers' reluctance to purchase hotel services online: what makes it so risky?”, Pasos, Vol. 14 No. 5, pp. 1253-1266.

Baek, T.H. and Karen, W.K. (2011), "Exploring the consequences of brand credibility in services", Journal of Services Marketing, Vol. 25 No. 4, pp. 260-272.

Bart, Y., Shankar, V., Sultan, F. and Urban, G.L. (2005), "Are the drivers and role of online trust the same for all web sites and consumers? A large-scale exploratory empirical study", Journal of Marketing, Vol. 69 No. 4, pp. 133-152.

Baz, J., Briys, E., Bronnenberg, B.J., Cohen, M., Kast, R., Viala, P. and Wertenbroch, K. (1999), "Risk perception in the short run and in the long run", Marketing Letters, Vol. 10 No. 3, pp. 267-283.

Boshoff, C. (2002), "Service advertising: an exploratory study of risk perceptions", Journal of Service Research, Vol. 4 No. 4, pp. 290-298.

Botsman, R. (2015), "Defining the sharing economy: what is collaborative consumption-and what isn't”, Fast Company, Vol. 27 No. 1, p. 2015.

Bourgeois, L.J. and Eisenhardt, K.M. (1988), "Strategic processes in high velocity environments: four cases in the Microcomputer industry", Management Science, Vol. 34 No. 7, pp. 816-835.

Bridges, J. and Vasquez, C. (2018), "If nearly all Airbnb reviews are positive, does that make them meaningless?”, Current Issues in Tourism, Vol. 21 No. 18, pp. 2057-2075.

Buhrmester, M., Kwang, T. and Gosling, S.D. (2016), “Amazon's Mechanical Turk: a new source of inexpensive, yet high-quality data?”, in Kazdin, A.E. (Ed.), Methodological Issues and Strategies in Clinical Research, American Psychological Association, pp. 133-139.

Cheng, M. and Jin, X. (2019), "What do Airbnb users care about? An analysis of online review comments", International Journal of Hospitality Management, Vol. 76 No. 1, pp. 58-70.

Christensen, C.M. (2013), The Innovator's Dilemma: When New Technologies Cause Great Firms to Fail, Harvard Business Review Press, Cambridge, MA.

Cunningham, L.F., Gerlach, J.H., Harper, M.D. and Young, C.E. (2005), "Perceived risk and the consumer buying process: internet airline reservations", International Journal of Service Industry Management, Vol. 16 No. 3, pp. 357-372.
Consumers' perceived risks of using Airbnb 
IHR

35,2

Curran, J.M. and Meuter, M.L. (2005), "Self-service technology adoption: comparing three technologies", Journal of Services Marketing, Vol. 19 No. 2, pp. 103-113.

D’Alessandro, S., Girardi, A. and Tiangsoongnern, L. (2012), "Perceived risk and trust as antecedents of online purchasing behavior in the USA gemstone industry", Asia Pacific Journal of Marketing and Logistics, Vol. 24 No. 3, pp. 433-460.

Dean, J.W. Jr and Sharfman, M.P. (1993), "Procedural rationality in the strategic decision-making process", Journal of Management Studies, Vol. 30 No. 4, pp. 587-610.

Dubin, A. (2020), "Which is safer: Airbnb or hotels? Here's what doctors say", Business Insider, available at: https://www.businessinsider.com/which-is-safer-airbnb-hotels-coronavirus (accessed 28 August 2020).

Ert, E., Fleischer, A. and Magen, N. (2016), "Trust and reputation in the sharing economy: the use of personal photos in Airbnb", Tourism Management, Vol. 55 No. 1, pp. 65-73.

Gefen, D. and Pavlou, D. (2012), "The boundaries of trust and risk: the quadratic moderating role of institutional structures", Information Systems Research, Vol. 23 No. 3, pp. 940-959.

Gradek, J. (2020), How COVID-19 Could Impact Travel for Years to Come, PhysOrg, available at: https://phys.org/news/2020-08-covid-impact-years.html.

Grewal, D., Gotlieb, J. and Marmorstein, H. (1994), "The moderating effects of message framing and source credibility on the price-perceived risk relationship", Journal of Consumer Research, Vol. 21 No. 1, pp. 145-153.

Grewal, D., Iyer, G.R., Gotlieb, J. and Levy, M. (2007), "Developing a deeper understanding of postpurchase perceived risk and behavioral intentions in a service setting", Academy of Marketing Science Journal, Vol. 35 No. 2, pp. 250-258.

Guttentag, D. (2015), "Airbnb: disruptive innovation and the rise of an informal tourism accommodation sector", Current Issues in Tourism, Vol. 8 No. 12, pp. 1192-1217.

Guttentag, D.A. and Smith, S.L. (2017), "Assessing Airbnb as a disruptive innovation relative to hotels: substitution and comparative performance expectations", International Journal of Hospitality Management, Vol. 64 No. 1, pp. 1-10.

Hamari, J., Sjöklint, M. and Ukkonen, A. (2016), "The sharing economy: why people participate in collaborative", Journal of the Association of Information Technology, Vol. 67 No. 9, pp. 2047-2059.

Havlena, W.J. and DeSarbo, W.S. (1991), "On the measurement of perceived consumer risk", Decision Sciences, Vol. 22 No. 4, pp. 927-939.

Heo, C.Y., Blal, I. and Choi, M. (2019), "What is happening in Paris? Airbnb, hotels, and the Parisian market: a case study", Tourism Management, Vol. 70 No. 1, pp. 78-88.

Ipsos (2020), "Coronavirus and behaviour change: what does it mean for brands?", available at: https:// www.ipsos.com/en/coronavirus-behaviour-change-what-does-it-mean- (accessed 26 March 2020).

Jun, S. (2020), "The effects of perceived risk, brand credibility and past experience on purchase intention in the Airbnb context", Sustainability, Vol. 12 No. 12, pp. 5212-5229.

Karahanna, E., Straub, D.W. and Chervany, N.L. (1999), "Information technology adoption across time: a cross-sectional comparison of pre-adoption and post-adoption beliefs", MIS Quarterly, Vol. 23 No. 2, pp. 183-213.

Kushwaha, T. and Shankar, V. (2013), "Are multichannel customers really more valuable? The moderating role of product category characteristics", Journal of Marketing, Vol. 77 No. 4, pp. 67-85.

Laroche, M., McDougall, G.H., Bergeron, J. and Yang, Z. (2004), "Exploring how intangibility affects perceived risk", Journal of Service Research, Vol. 6 No. 4, pp. 373-389.

Lee, S.H. (2020), "New measuring stick on sharing accommodation: guest-perceived benefits and risks", International Journal of Hospitality Management, Vol. 87, p. 102471. 
Lee, K. and Khan, M.A. (2012), "Exploring the impacts of service guarantee strategy", Journal of Travel and Tourism Marketing, Vol. 29 No. 2, p. 133.

Liang, L. (2015), Understanding Repurchase Intention of Airbnb Consumers: Perceived Authenticity, EWoM and Price Sensitivity, M.S. Thesis, University of Guelph, available at: https://atrium.lib.uoguelph.ca/xmlui/bitstream/handle/10214/8813/Liang_Jingen_201505_ Msc.pdf?sequence $=3 \&$ is Allowed $=\mathrm{y}$ (accessed 26 August 2020).

Liang, L.J., Choi, H.S.C. and Joppe, M. (2018), "Understanding repurchase intention of Airbnb consumers: perceived authenticity, electronic word-of-mouth, and price sensitivity", International Journal of Hospitality Management, Vol. 38 No. 1, pp. 73-89.

Mao, Z. and Lyu, J. (2017), "Why travelers use Airbnb again? An integrative approach to understanding travelers' repurchase intention", International Journal of Contemporary Hospitality Management, Vol. 29 No. 9, pp. 2464-2482.

Mody, M.A., Suess, C. and Lehto, X. (2017), "The accommodation experiencescape: a comparative assessment of hotels and Airbnb", International Journal of Contemporary Hospitality Management, Vol. 29 No. 9, pp. 2377-2404.

Mody, M., Suess, C. and Lehto, X. (2019), "Going back to its roots: can hospitableness provide hotels competitive advantage over the sharing economy?", International Journal of Hospitality Management, Vol. 76, pp. 286-298.

Mohamed, T. (2020), "Airbnb IPO could be the 'steal of the century' if people keep switching from hotels to homes, Jim Cramer says", Business Insider, available at: https://news.yahoo.com/ airbnb-ipo-could-steal-century-105012112.html (accessed 26 August 2020).

Murray, K.B. and Schlacter, J.L. (1990), "The impact of services versus goods on consumers' assessment of perceived risk and variability", Journal of the Academy of Marketing Science, Vol. 18 No. 1, pp. 51-65.

Nguyen, Q. (2014), “A study of Airbnb as a potential competitor of the hotel industry”, UNLV Theses, Dissertations, Professional Papers, and Capstones. 2618, available at: https://digitalscholarship. unlv.edu/thesesdissertations/2618 (accessed 26 August 2020).

Outdoorsy (2020), available at: https://www.outdoorsy.com/ (accessed 28 August 2020).

Ovide, S. (2020), “The pandemic is straining Airbnb”, The New York Times, available at: https://www. nytimes.com/2020/07/17/technology/airbnb-coronavirus.html (accessed 25 August 2020).

Phua, V.C. (2019), "Perceiving Airbnb as sharing economy: the issue of trust in using Airbnb", Current Issues in Tourism, Vol. 22 No. 17, pp. 2051-2055.

Pires, G., Stanton, J. and Eckford, A. (2004), "Influences on the perceived risk of purchasing online", Journal of Consumer Behaviour, Vol. 4 No. 2, pp. 118-131.

Raju, P.S., Lonial, S.C. and Mangold, W.G. (1995), "Differential effects of subjective knowledge, objective knowledge, and usage experience on decision making: an exploratory investigation", Journal of Consumer Psychology, Vol. 4 No. 2, pp. 153-180.

Roof, K. and Carville, O. (2020), Airbnb Quarterly Revenue Drops 67\%; IPO Still Planned, Bloomberg News, available at: https://www.bloomberg.com/news/articles/2020-08-12/airbnb-revenue-tanks67-in-second-quarter-ipo-planned-for-2020 (accessed 26 August 2020).

Shen, A.X., Cheung, C.M., Lee, M.K. and Chen, H. (2011), "How social influence affects we-intention to use instant messaging: the moderating effect of usage experience", Information Systems Frontiers, Vol. 13 No. 2, pp. 157-169.

Shimp, T.A. and Bearden, W.O. (1982), "Warranty and other extrinsic cue effects on consumers' risk perceptions", Journal of Consumer Research, Vol. 9 No. 1, pp. 38-46.

Skard, S. and Nysveen, H. (2016), "Trusting beliefs and loyalty in B-to-B self-services", Journal of Business-To-Business Marketing, Vol. 23 No. 4, pp. 257-276.

So, K.K.F., Oh, H. and Somang, M. (2018), "Motivations and constraints of Airbnb consumers: findings from a mixed-methods approach", Tourism Management, Vol. 67 No. 1, pp. 224-236.
Consumers' perceived risks of using Airbnb

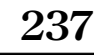


IHR

35,2

\section{8}

Sozzi, B. (2020), This Airbnb of the RV Industry Is Seeing Sales Explode during the COVID-19 Pandemic, Yahoo News, available at: https://finance.yahoo.com/news/this-airbnb-of-the-rvindustry-is-seeing-sales-explode-during-the-covid-19-pandemic-181210876.html (accessed 26 August 2020).

Statista.com (2019), Company Value of Airbnb from 2016 to 2018 (In Billion U.S. Dollars), Statista.com, available at: https:/www.statista.com/statistics/339845/ company-value-andequity-funding-of-airbnb/.

Stone, R.N. and Gronhaug, K. (1993), "Perceived risk: further considerations for the marketing discipline", European Journal of Marketing, Vol. 27 No. 3, pp. 39-50.

Sun, J. (2014), "How risky are services? An empirical investigation on the antecedents and consequences of perceived risk for hotel service", International Journal of Hospitality Management, Vol. 37, pp. 171-179.

Sutton, R.I., Eisenhardt, K.M. and Jucker, J.V. (1986), "Managing organizational decline: lessons from atari”, Organizational Dynamics, Vol. 14 No. 4, pp. 17-29.

Sweeney, J.C., Soutar, G.N. and Johnson, L.W. (1999), "The role of perceived risk in the quality-value relationship: a study in a retail environment", Journal of Retailing, Vol. 75 No. 1, pp. 77-105.

Taylor, J.I. (2020), "Airbnb hosts send 40K+ letters to congress pleading for financial relief from coronavirus", Florida Politics (FLAPOL), available at: https://floridapolitics.com/archives/ 324696-airbnb-hosts-send-40k-letters-to-congress-pleading-for-financial-relief-from-coronavirus (accessed 26 August 2020).

Thompson, R.L., Higgins, C.A. and Howell, J.M. (1994), "Influence of experience on personal computer utilization: testing a conceptual model”, Journal of Management Information Systems, Vol. 11 No. 1, pp. 167-187.

Tussyadiah, I.P. and Pesonen, J. (2016), "Impacts of peer-to-peer accommodation use on travel patterns", Journal of Travel Research, Vol. 55 No. 1, pp. 1022-1040.

United Nations (2020), "Policy Brief: COVID-19 and transforming tourism", available at: https://www. un.org/sites/un2.un.org/files/sg_policy_brief_covid-19_tourism_august_2020.pdf (accessed 26 August 2020).

United Nations World Tourism Organization (UNWTO) (2020), "Impact assessment of the COVID-19 outbreak on international tourism", available at: https://www.unwto.org/impact-assessment-ofthe-covid-19-outbreak-on-international-tourism.

United Nations World Tourism Organization (UNWTO a) (2020), "World tourism barometer", Madrid, available at: www.e-unwto.org/doi/abs/10.18111/wtobarometereng. wtobarometereng.2020.18.1. 3 (accessed 26 August 2020).Vol. 8 No. 43.

United Nations World Tourism Organization (UNWTO b) (2020), "World tourism barometer", Madrid, available at: //www.e-unwto.org/doi/abs/10.18111/wtobarometereng.2020.18.1.4 (from 26 August 2020).Vol. 8 No. 4.

Wirtz, J., Kum, D. and Lee, K.S. (2000), "Should a firm with a reputation for outstanding service quality offer a service guarantee?", Journal of Services Marketing, Vol. 14 No. 6, pp. 502-512.

Xie, K. and Mao, Z. (2017), "The impacts of quality and quantity attributes of Airbnb hosts on listing performance", International Journal of Contemporary Hospitality Management, Vol. 29 No. 9, pp. 2240-2260.

Yang, Y., Liu, Y., Li, H. and Yu, B. (2015), "Understanding perceived risks in mobile payment acceptance”, Industrial Management and Data Systems, Vol. 115 No. 2, pp. 253-269.

Young, C.A., Corsun, D.L. and Xie, K.L. (2017), "Travelers' preferences for peer-to-peer(P2P) accommodations and hotels", International of Cultural Tourism and Hospitality Research, Vol. 11 No. 4, pp. 465-482.

Yuko, E. (2020), 13 Everyday Habits that Could (And Should) Change Forever after Coronavirus, RD.COM, available at: https://www.rd.com/list/everyday-habits-that-could-change-forever-aftercoronavirus/ (accessed 9 September 2020). 
Zervas, G., Proserpio, D. and Byers, J.W. (2017), "The rise of the sharing economy: estimating the impact of Airbnb on the hotel industry", Journal of Marketing Research, Vol. 54 No. 5, pp. 687-705.

Zhau, Y., Cheng, M., Wanga, J., Mad, L. and Jiang, R. (2019), "The construction of home feeling by Airbnb guests in the sharing economy: a semantics perspective", Annal of Tourism Research, Vol. 75 No. 1, pp. 308-321.

Zhenxing, M., Jones, M.F., Li, M. and Lyu, J. (2020), "Sleeping in a stranger's home: a trust formation model for Airbnb", Journal of Hospitality and Tourism Management, Vol. 42 No. 1, pp. 67-76.
Consumers' perceived risks of using Airbnb

\section{Appendix \\ Descriptive analysis}

\begin{tabular}{lllll}
\hline & \multicolumn{2}{c}{ Pre-test } & \multicolumn{2}{c}{ Peri-test } \\
& Mean & SD & Mean & SD \\
\hline Social risks & & & & \\
I may be seen that I am unable to rent a proper hotel & 2.24 & 1.15 & 3.26 & 1.24 \\
Others may think that using it is low class & 2.23 & 1.12 & 3.29 & 1.34 \\
Others may view me as cheap & 2.24 & 1.15 & 3.27 & 1.29 \\
Others may judge me for making a bad choice & 2.38 & 1.12 & 3.27 & 1.26 \\
Physical risks & & & & \\
Place is not clean & 3.23 & 1.03 & 3.46 & 1.16 \\
It may be in a poor, unsafe, remote neighborhood & 3.41 & 1.02 & 3.75 & 0.97 \\
Despite background verification, there could be a chance that the host may & 3.38 & 1.11 & 3.66 & 1.04 \\
turn hostile or harass me & & & & \\
There is a possibility of burglary, break-in, or theft & 3.32 & 1 & 3.63 & 1.11 \\
Performance risks & & & & \\
It is difficult to tell from a photo how the place really looks & 3.35 & 1.01 & 3.71 & 1.01 \\
Photos may be misleading and not representative of the place & 3.52 & 0.98 & 3.81 & 1.04 \\
Performance may not be as consistent as hotels & 3.53 & 1.04 & 3.85 & 0.95 \\
Convenience risks & & & & \\
It takes longer to check in & 2.99 & 1.03 & 3.48 & 1.14 \\
It takes more time to make choices & 3.09 & 1.12 & 3.66 & 1.03 \\
If something goes wrong during check-out, there is no one else on site to help & 3.42 & 1.03 & 3.78 & 0.89 \\
Deside the & & & &
\end{tabular}

besides the host

Note(s): 5-point Likert scale was used; the scale was adapted from Lee's (2020) study

\section{Corresponding author}

Seung Hyun Lee can be contacted at: leese14@ecu.edu

For instructions on how to order reprints of this article, please visit our website:

www.emeraldgrouppublishing.com/licensing/reprints.htm

Or contact us for further details: permissions@emeraldinsight.com 